\title{
Organizational Commitment of Non-Profit Organization Volunteers: A Study on the Save Street Child (SSC) Organization in Malang City, Indonesia
}

\author{
Noermijati ${ }^{1}$, Ikhwan $\mathrm{HS}^{2}$ \\ ${ }^{1}$ Faculty of Economics and Business, Brawijaya University, Indonesia \\ ${ }^{2}$ Faculty of Economics and Business, Gunadarma University, Indonesia \\ Correspondence: Ikhwan, HS, Faculty of Economics and Business, Gunadarma University, Depok, West Java \\ Province 16424, Indonesia.
}

Received: September 18, 2017

Accepted: October 9, 2017

Online Published: July 25, 2018

doi:10.5539/ibr.v11n8p154

URL: https://doi.org/10.5539/ibr.v11n8p154

\begin{abstract}
Save Street Child (SSC) is a nonprofit organization in which its main activity is focused on the empowerment of the street children. This research aims at analyzing the effect of organizational culture on organizational commitment, analyzing the job satisfaction as the mediating variable of the organizational culture's influence on the organizational commitment, and analyzing the volunteering tenure as the moderating variable of the organizational culture's influence on the organizational commitment. This research involved all of 63 volunteers in SSC organization in Malang City as respondents. Closed questionnaires were used to collect the primary data. Further, the data were analyzed by using the PLS (Partial Least Square). The research results show that the organizational culture affects the job satisfaction, whereas the organizational culture does not have any influence on the organizational commitment. In addition, the job satisfaction influences the organizational commitment, and it also becomes the mediating variable of the influence of the organizational culture on the organizational commitment. The last finding also shows that the volunteering tenure is not the moderating variable of the organizational culture's influence on the organizational commitment. This study is useful for understanding organizational culture, job satisfaction, and organizational commitment in nonprofit organizations.
\end{abstract}

Keywords: organizational culture, organizational commitment, job satisfaction, volunteering tenure, save street child, nonprofit organization

\section{Introduction}

In this globalization era, non-profit organization has an important role in resolving many social problems. One of the non-profit organization which engages in the community service is Save Street Child. Its presence has covered some big cities in Indonesia, including Malang. Save Street Child (SSC) is a non-profit organization in Malang focusing on street children. Its main activity is the empowerment of street children involving advising and educating them to realize and change their habitual activity of earning the life on the street.

SSC organization is driven by volunteers; thus its existence depends much on its volunteers. The volunteer is an individual who has high concern on the problems faced by people in his/her surrounding without asking anything in return. Hodgkinson (2003) states that volunteers even engage in overcoming environmental and society various problems either in government organizations or companies. Therefore, to be able to perform their function well, volunteers need to have high commitment.

Volunteers' organizational commitment has close connection with the values or the organizational culture, and also the volunteers' satisfaction in conducting their social activities. A strong organizational culture is expected to be able to elevate the volunteer's commitment to remain to stay and not to leave the organization. The strong organizational culture will be able to increase the job satisfaction of the organizational members (Dirani, 2009; Macintosh \& Doherty, 2010). Furthermore, the organizational members who have obtained job satisfaction will also hold a high commitment. It is in line with the results of the researches conducted by Zeinabadi \& Salehi (2011), Prabowo et al. (2016) who state that the job satisfaction affects the organizational commitment. In addition, studies conducted by McKinnon et al. (2003) and Al-Amin and Noermijati (2010), show that the organizational culture influences the organizational commitment. In contrary to the results of the empirical 
studies above, Jain (2015) shows that sociability and solidarity culture does not have any correlation to the continuance commitment.

On the basis of the previous empirical research results, this study has a research gap which differs it from others. This study uses the job satisfaction as the mediating variable. This gap refers to the statement that the strong organizational culture will increase the job satisfaction of the members (Dirani, 2009; Macintosh \& Doherty, 2010). Meanwhile, every organizational member who have already perceived the job satisfaction, will also hold a high commitment (Zeinabadi \& Salehi, 2011; Prabowo et al. 2016). In addition, this study also takes the volunteering tenure as the moderating variable of the influence of the organizational culture on the organizational commitment. This moderating variable is used to find out whether the time period of being a volunteer in SSC will strengthen or weaken the effect of the organizational culture on the volunteer's organizational commitment. Robbins and Judge (2013) state that the volunteering tenure can be a strong predictor of the volunteer's intention to leave. It can also be inferred that the longer of the members pursue certain works, the higher the members' commitments will be on the organization. Therefore, this study intends to disclose whether the same hypothesis will also work on the volunteers of the non-profit organization or not. Moreover, the originality of this research focuses on the volunteer commitment, and put the volunteering tenure as the moderating variable of the effect of the organizational culture on the volunteer's organizational commitment.

The paper is organized as follows: The next section provides a review of the theoretical literature, some previous study, and sets out the hypotheses of the study. The research methods are presented in the section 3 . The next section results of statistical analysis are presented followed by conclusion and managerial implications in section 5 .

\section{Literature Review}

\subsection{Organizational Culture}

According to Robbins (2006), the organizational culture is defined as a perception held by all the organizational members or the shared meaning of the system which is considered as the characteristics set adopted by an organization. Kotter dan Heskett (1997) state that the organizational culture has two levels, which are: the first, a deep and less visible level which is an organizational culture refers to the shared values among the organizational members which also tend to persist over time; meanwhile, for the second refers to more visible level in which a culture portrays organization's behavior or pattern, so that it is expected that new members automatically feel supported to follow their co-workers. Moreover, Luthan (2006) defines the organizational culture as a norm and value directing the organizational member behavior. In addition, Schein (2010) also states that the organizational culture is a glue between the members and organizational system that held together and stimulates the members' commitment and performance. Basically, a culture is the totality of social behavior patterns, arts, beliefs, and institutions; while the essence of the organizational culture is a norm of act of the organization as well as its members. The strong culture affects the members to be embedded with the organization's goals and work together to achieve the goals. It also notifies the members of how things are done and what things are important to do. The study of Lok dan Crawford (2004) disclose that there is a correlation of the organizational culture on the job satisfaction and organizational commitment. Meanwhile, another research conducted by Nurjanah (2008) aimed at finding out the influence of the leadership style and organizational culture on the organizational commitment and employee performance. The result shows that the organizational culture has a significant and positive effect on the organizational commitment. Other previous studies from McKinnon et al. (2003); Zain et al. (2009); Al-Amin and Noermijati (2010) also show that the organizational culture has an effect on the organizational commitment.

Furthermore, Cartwright (1999) state that a culture has a strength and authority to create personality, behavior, and attitude characteristics of an individual. Based on Cartwright (1999), it can be inferred that the organizational culture has an influence in forming the individual personality, behavior, and attitude. In order to measure the organizational culture, Cartwright found nine motivation factors which also become a base of the culture measurement/indicator, which are Identification, Equity, Equalit, Consensus, Instrumentality, Rationality, Development, Group Dynamics, Internalization.

The organizational culture in SSC is measured by using indicators adopted from Cartwright and other indicators that fit the condition of the research object. The indicators consist of: (1) equity: the balance between the aqcuired reward and experience and the volunteer's desired; (2) equality: the equal treatment and respect among volunteers, regardless of status, seniority, and the contribution made; (3) communication: the relationship conducted through communication among volunteers; (4) Empathy: there is more understanding and caring among volunteers; and (5) technology: the use of the application and socal media to assist the coordination, take 
decision, and disseminate information to other volunteers.

\subsection{Job Satisfaction}

According to Robin and Judge (2013), the job satisfaction is a positive feeling of certain works resulted from the assessment of the work characteristics. An employee with high job satisfaction has a positive assessment or feeling towards his/her job, it also happens vice versa. Meanwhile, Flannery et al. (2008) states that the job satisfaction is an individual attitude towards his/her job reflected as a self-attitude on the tendency and response of the job being done at the level of pleasure or displeasure. This self-attitude refers to either the visible or invisible individual attitude. Locke (1970) published a job satisfaction theory well-known as Range of Affect Theory which describes that the employee job satisfaction is measured through the wishes differentiation of which the employees earn from their job. Parker (2007) mentions the three matters are known to lead to the job satisfaction: job situation, employee characteristics, and the result of the employee interaction.

Locke (1970) states that there are five indicators of the job satisfaction: The Work Itself, Pay, Promotion Opportunities, Supervision, Coworkers. In correlation to the volunteer job satisfaction, there is a high expectation of the volunteers to be able to fulfill their desire that is by working better as the volunteers, receiving rewards of what they have done, and developing themselves. Considering these, it needs an adjustment of the job satisfaction indicators. Therefore, referring to the five job satisfaction indicators proposed by Locke (1970), the two indicators are considered being adjusted based on the condition of the research object which is to measure the job satisfaction of the volunteers in SSC Malang. Indicators of the volunteer job satisfaction are as follows: (1) The Work Itself: how far the voluntary work provides chances to volunteers to have interesting work, opportunity to learn, and opportunity to accept responsibility; (2) Appreciation: rewards received by volunteers for their contribution to the organization; (3) Development Opportunities: the opportunities for volunteers to develop; (4) Supervision: the capability of the supervisor or division coordinator to provide technical and moral supports for volunteers; (5) Coworkers: coworkers have a great role in creating a conducive working environment and high job satisfaction.

\subsection{Organizational Commitment}

Luthan (2006) states that organizational commitment is an attitude showing the loyalty of employees and considered as a continuous process of how the members of the organization express their interest on the success and the good of the organization. Furthermore, the loyalty is indicated through three important matters which are: 1). the strong desire of the individual to stay as an organizational member; 2) the desire to exert the efforts for the sake of the organization; 3 ). the belief and strong acceptance on the aims and values of the organization. Allen and Meyer (1991) define organizational commitment as a psychological construct portraying the relationship between the members of the organization and their organization, and having implications on the individual decision to continue their organizational membership. Allen and Meyer (1991) also introduce a model named Three Component Model (TCM) including affective commitment; continuance commitment; normative commitment. Furthermore, the three components become the measurement indicators of the organizational commitment variable in this study.

Organizational commitment can be expressed as a sense of emotional attachment of the individual / members in an organization which allows them to prefer to keep remaining in the organization than those who have no involvement to the organization. The members who have high commitment also have a strong involvement. In addition, the organizational members who also have high commitment will have more possibilities to stay than those who have no commitment. A study conducted by Puspitawati (2013) aimed at disclosing the influence of job satisfaction on the organizational commitment and service quality at Hotel Bali Hyatt Sanur. The results show that the job satisfaction positively and significantly affects the organizational commitment. Moreover, the organizational members who obtain the job satisfaction will also have a high commitment. These results are in line with the studies conducted by Zeinabadi \& Salehi (2011); Fraga et al. (2015); Prabowo et al. (2016) disclosing that the job satisfaction effects the organizational commitment.

\subsection{Volunteering Tenure}

The length period of being volunteers is also considered identic to the volunteering tenure. Tenure can be defined as a working time at a certain position or also as a job experience (Robin \& Judge, 2013). Tenure refers to how long an individual pursues a particular occupation meaning that the longer the person stays working in certain position, the more experience he/she will get. English et al. (2010) divide the working period into three stages, which are early, middle, and later stage. The research results of English et al. (2010) show that at certain different tenure stages, it is found that there is also a different strength of affective commitment. Noermijati (2015) in her research divides the working period into two, which are the new and old working period. Therefore, in this study, 
the volunteers of SSC Malang, a non-profit organization in Malang, can be divided into two which are the newcomers and long-time members.

This research analyzes the influence of organizational culture on organizational commitment which is mediated by job satisfaction and moderated by volunteering tenure:

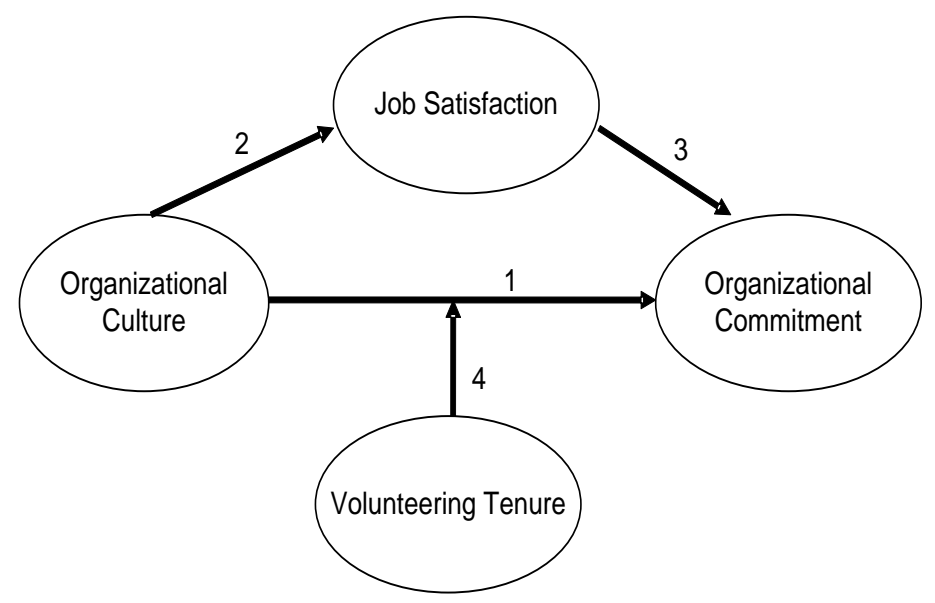

Figure 1. Research Framework

Referring to the review of related literature above, there are five research hypotheses which can be mentioned as follows:

H1: Organizational culture influences organizational commitment

$\mathrm{H} 2$ : Organizational culture influences volunteer's job satisfaction

H3: Job satisfaction influences volunteer's organizational commitment

H4: Job satisfaction mediates the influence of organizational culture on volunteer's organizational commitment.

H5: Volunteering tenure moderates the influence of organizational culture on volunteer's organizational commitment.

\section{Research Methods}

This research involved the entire population members, which were 63 volunteers of non-profit organization, SSC Malang as the research respondents. Sampling technique used was census method. Data gathering was done by distributing questionnaire and documentation. The respondents' answers were measured by using 5 Likert scales. The data were analyzed by using statistic technique PLS (Partial Least Square).

Table 1. Variable Measurement

\begin{tabular}{lll}
\hline No. & \multicolumn{1}{c}{ Variable } & Indicator \\
\hline & & Equity \\
1. & Organizational Culture (Cartwright, 1999) & Equality \\
& & Communication \\
& & Empathy \\
& & Technology \\
2. & Job satisfaction (Locke,1970) & The work itself \\
& & Appreciation \\
& & Development opportunities \\
3. & Organizational Commitment (Meyer snf Allen,1991) & Supervision \\
4. & Volunteering Tenure ( Noermijati, 2015) & Co-workers \\
\hline
\end{tabular}

Respondents' characteristic included gender, age, education and occupation. The numbers of female respondents were bigger than males, which is $65 \%$ female and $35 \%$ male. Majority $(81 \%)$ of the respondents are between 20-30 years old and 19\% is below 20 years old. Respondents with Bachelor Degree (S1) have the majority percentage 52\%, S2 1\% and Junior High School 41\%. Based on the volunteering tenure, the majority of SSC Malang volunteers has joined the organization for more than 12 months $(63 \%)$, and the rest has joined less than 12 months. 


\section{Data Analysis and Findings}

\subsection{Outer Model Evaluation}

Based on the testing result of convergent validity, it shows that all research indicators are valid in measuring its own research variable.

Table 2. Testing of Discriminant Validity using Cross Loading

\begin{tabular}{|c|c|c|c|c|}
\hline Item & Organizational Culture & Job satisfaction & $\begin{array}{l}\text { Organizational } \\
\text { Commitment }\end{array}$ & Volunteering Tenure \\
\hline A.2.3 & 0.756 & $\begin{array}{l}-0.058 \\
\end{array}$ & 0.007 & 0.239 \\
\hline A. 3.1 & 0.618 & 0.368 & -0.180 & -0.087 \\
\hline A.3.2 & 0.617 & 0.023 & -0.237 & -0.147 \\
\hline A. 3.3 & 0.692 & -0.318 & 0.05 & 0.106 \\
\hline A. 4.1 & 0.740 & -0.109 & 0.075 & -0.218 \\
\hline A. 4.2 & 0.737 & 0.129 & 0.089 & 0.038 \\
\hline A. 4.3 & 0.675 & 0.004 & 0.034 & 0.129 \\
\hline A.1.2 & 0.528 & -0.166 & 0.148 & 0.136 \\
\hline A. 2.1 & 0.653 & 0.488 & -0.099 & -0.079 \\
\hline A. 2.2 & 0.645 & -0.351 & 0.092 & -0.130 \\
\hline C. 1.1 & 0.024 & 0.654 & 0.319 & 0.268 \\
\hline C. 2.1 & -0.090 & 0.773 & -0.064 & 0.187 \\
\hline C. 2.3 & -0.376 & 0.72 & -0.034 & 0.115 \\
\hline C. 4.1 & 0.132 & 0.703 & -0.083 & -0.153 \\
\hline C. 4.2 & -0.247 & 0.608 & 0.055 & -0.261 \\
\hline C. 5.2 & 0.232 & 0.810 & -0.117 & -0.058 \\
\hline C.5.3 & -0.169 & 0.662 & -0.086 & -0.218 \\
\hline C. 3.1 & 0.209 & 0.537 & -0.048 & 0.376 \\
\hline C. 2.2 & -0.180 & 0.657 & -0.127 & -0.107 \\
\hline C. 4.3 & 0.215 & 0.530 & 0.106 & 0.106 \\
\hline C. 5.1 & 0.342 & 0.581 & 0.164 & -0.229 \\
\hline E.1.2 & -0.182 & 0.036 & 0.650 & -0.062 \\
\hline E.1.3 & 0.005 & 0.026 & 0.712 & 0.168 \\
\hline E. 2.3 & -0.063 & 0.229 & 0.810 & 0.115 \\
\hline E.3.3 & -0.042 & 0.200 & 0.778 & 0.233 \\
\hline E.3.1 & 0.229 & -0.689 & 0.531 & -0.130 \\
\hline E.1.1 & -0.057 & -0.056 & 0.536 & -0.180 \\
\hline E. 2.1 & 0.106 & -0.176 & 0.539 & -0.455 \\
\hline E. 2.2 & 0.139 & -0.277 & 0.521 & 0.008 \\
\hline E.3.2 & -0.043 & 0.462 & 0.543 & 0.098 \\
\hline LR & 0 & 0 & 0 & 1.000 \\
\hline
\end{tabular}

Based on the testing result of discriminant validity using cross loading on Table 2, it indicates that the indicators predict its own latent variable better than other latent variable indicator. Based on the analysis result, it can be interpreted that the testing of discriminant validity has been fulfilled.

Based on the testing result of composite reliability, the composite reliability score of each research variable is: 1) organizational culture 0.889 ; 2) job satisfaction 0.895 ; 3) organizational commitment 0.854 ; 4) volunteering tenure 1.000. The testing result of Composite Reliability shows that the score of organizational culture, job satisfaction, commitment and volunteering tenure variable is bigger than 0.70 , thus the model has fulfilled the criteria of discriminant validity (all construction on organizational culture, job satisfaction, commitment and volunteering tenure indicator strengthen each of its latent variable or able to measure its latent variable).

\subsection{Inner Model Evaluation}

Based on the Testing of inner was found that job satisfaction has influence with prediction score of the entire model $\underline{0.512}$ or $51.2 \%$. Commitment variable has influence with prediction score $\underline{0.215}$ or $21.5 \%$. Moreover, the testing on inner model can also be seen from the evaluation of predictive relevance stone-geiser Q-square test for predictive relevance. $\mathrm{R}$-square score is put into Q-square equation as follows:

$\mathrm{Q}^{2}=1-\left(1-\mathrm{R}_{1}{ }^{2}\right)\left(1-\mathrm{R}_{2}{ }^{2}\right) \ldots\left(1-\mathrm{Rp}^{2}\right)$

Based on Q-square evaluation, it shows that the model has predictive relevance because it has the value of 0.61692 which is bigger that 0 (zero), therefore the model is good to be used.

\subsection{Hypothesis Testing}

The hypothesis testing result by using PLS and Sobel formula can be seen on Table 3-5 
Table 3. Direct Testing of Path Coefficient

\begin{tabular}{|c|c|c|c|c|c|}
\hline Variable & Path Coefficient & $\begin{array}{l}\text { Deviation } \\
\text { Standard } \\
\end{array}$ & P Values & \multicolumn{2}{|c|}{ Remarks } \\
\hline Organizational culture -> organizational commitment & 0.165 & 0.119 & 0.086 & \multicolumn{2}{|c|}{ Insignificant } \\
\hline Organizational culture -> job satisfaction & 0.711 & 0.099 & $<0.001$ & \multicolumn{2}{|c|}{ Significant } \\
\hline job satisfaction $->$ organizational commitment & 0.458 & 0.108 & $<0.001$ & \multicolumn{2}{|c|}{ Significant } \\
\hline \multicolumn{6}{|c|}{ Table 4. Indirect Effect of Coefficient Path, and Moderation Role } \\
\hline Variable & & $\begin{array}{l}\text { Path } \\
\text { Coefficient }\end{array}$ & $\begin{array}{l}\text { Deviation } \\
\text { Standard } \\
\end{array}$ & $\begin{array}{l}\mathrm{P} \\
\text { Values }\end{array}$ & Remarks \\
\hline $\begin{array}{lllll}\begin{array}{l}\text { Organizational } \\
\text { Commitment }\end{array} & \text { culture } \rightarrow & \text { job } & \text { satisfaction } & \rightarrow \\
\end{array}$ & Organizational & 0.343 & 0.079 & $<0.001$ & Significant \\
\hline $\begin{array}{l}\text { Volunteering tenure } * \text { Organizational culture } \rightarrow \\
\text { commitment }\end{array}$ & Organizational & -0.027 & 0.125 & 0.414 & $\begin{array}{l}\text { Insignifica } \\
\text { nt }\end{array}$ \\
\hline \multicolumn{6}{|c|}{ Table 5. Moderation Testing without Involving Mediation Variable } \\
\hline Variable & & $\begin{array}{l}\text { Path } \\
\text { Coefficient }\end{array}$ & $\begin{array}{l}\text { Deviation } \\
\text { Standard }\end{array}$ & $\begin{array}{l}\mathrm{P} \\
\text { Values }\end{array}$ & Remarks \\
\hline Organizational culture $\rightarrow$ Organizational Commitment & & 0.405 & 0.110 & $<0.001$ & Significant \\
\hline $\begin{array}{l}\text { Volunteering tenure } * \text { Organizational culture } \rightarrow \\
\text { commitment }\end{array}$ & Organizational & -0.017 & 0.125 & 0.446 & $\begin{array}{l}\text { Insignifica } \\
\text { nt }\end{array}$ \\
\hline
\end{tabular}

Hypothesis testing is conducted to find out the influence among variables. If p-value is less than 0.05 then it is significant and thus research hypothesis is accepted, and vice versa. If p-value is more than 0.05 then it is insignificant and thus research hypothesis is rejected.

H1: Organizational culture influences organizational commitment

The testing result on Table 4 shows p-value score of direct effect of organizational culture on organizational commitment 0.09 , which is above 0.05 (insignificant), thus $\mathrm{H} 1$ is rejected and interpreted that organizational culture does not influence organizational commitment.

$\mathrm{H} 2$ : Organizational culture influences volunteer's job satisfaction

With $99 \%$ assurance, testing result on Table 4 shows that organizational culture has the significant positive influence on job satisfaction $(\beta=0.71, \mathrm{P}<0.01)$ which is shown by significant score $<0.01$. Therefore $\mathrm{H} 2$ is accepted.

H3: Job satisfaction influences volunteer's organizational commitment

With $99 \%$ assurance, testing result on Table 4 shows that job satisfaction has significant positive influence on commitment $(\beta=0.458, \mathrm{P}<0.01)$ which is shown by the significant score $<0.01$. Thus $\mathrm{H} 3$ is accepted and interpreted that the higher volunteer's job satisfaction level, it will significantly influence on the increasing of organizational commitment.

H4: Job satisfaction mediates the influence of organizational culture on volunteer's organizational commitment.

Referring to Table 4 and Table 5 which show that organizational culture does not significantly influence organizational commitment, while the organizational culture influences job satisfaction, and job satisfaction significantly influences organizational commitment, moreover the test result of the indirect effect of the organizational culture on the organizational commitment through job satisfaction is not significant, thus it can be concluded that job satisfaction fully mediates the influence of organizational culture on organizational commitment. It shows that the organizational culture will only influence organizational commitment through volunteer's job satisfaction.

H5: Volunteering tenure moderates the influence of organizational culture on volunteer's organizational commitment.

The hypothesis test result shows that the moderation role of volunteering tenure on the influence of organizational culture on organizational commitment, involving mediation variable $(\mathrm{P}-\mathrm{Value}=0.41)$ and not involving ( $\mathrm{P}$-Value $=0.44$ ), the result shows that $\mathrm{P}$-Value score $>0.05$ (insignificant), therefore $\mathrm{H} 5$ is rejected. It means that volunteering tenure does not moderate or neither strengthen nor weaken the influence of organizational culture on the organizational commitment.

\section{Discussions}

\subsection{Organizational Culture Influences Organizational Commitment}

Organizational culture does not influence organizational commitment. Descriptive analysis result shows that 
volunteers perceive a strong organizational culture in SSC organization. Volunteers have high commitment; commitment indicator with highest perceived score is affective commitment indicator with quite high average score, while the lowest commitment indicator is continuant commitment indicator. It means that the volunteers of SSC Malang feel comfort and want to be a part of the organization, which is shown by the high score of affective and continuant commitment. This shows that the volunteers of SSC Malang have a strong will to stay in the organizational, no intention to leave and also have a strong organizational commitment. Organizational culture does not significantly influence organizational commitment; this can be caused by the condition when the volunteers are graduated, they are expected to expand their career in other city or place. Since most of the volunteers are university students, thus after they completed their study and work at another city, then they have to leave Malang and also their role as volunteers at SSC. This research result does not support the researches of McKinnon et al. (2003); Al-Amin and Noermijati (2010) which states that organizational culture influences the organizational commitment.

\subsection{Organizational Culture Influences Job Satisfaction}

Organizational culture is a profound value of an organization which is manifested into how employees are expected to behave. Organizational culture which emphasizes on the value of companionship, mentor and respect of each other will be able to increase the job satisfaction of volunteers. Organizational culture which is measured by 15 items shows that, according to the respondents' perception, the organizational culture of SSC is already in a solid level. It means that the volunteers have felt the strong organizational culture in SSC. The organizational culture indicator which is perceived with the highest average score is technology indicator, while empathy indicator gains the lowest average score even though it is still at the average-high level. Technology does not only play a very important role in the transmission of information and decision making, but also as a medium to spread and internalize the organizational culture of SSC, especially for the newly joined volunteers. What needs attention is the empathy of volunteers. It still needs to be improved in order to enhance understanding and concern between volunteers in order for them to be more satisfied. This research result is in line with the researches of Lund (2003); Bellou (2010); Dirani (2009); MacIntosh \& Doherty (2010); Dinar et al (2017), which states that organizational culture influences the job satisfaction of employees.

\subsection{Job Satisfaction Mediates the Influence of Organizational Culture on Organizational Commitment}

Organizational culture does not have significant direct influence on organizational commitment. However, organizational culture will only influence organizational commitment through job satisfaction. Therefore, it can be concluded that job satisfaction fully mediates the influence of organizational culture on organizational commitment, and that organizational culture will only influence organizational commitment when the volunteers reach job satisfaction. Here, the role of the volunteer's satisfaction is very important so that the strong organizational culture of SSC will be able to keep the volunteers as members of SSC organizational Malang.

\subsection{Volunteering Tenure Moderates the Influence of Organizational Culture on Organizational Commitment}

Volunteering tenure eventually does not strengthen or weaken the influence of organization culture on organizational commitment. Whether it is new or old volunteer, it will not strengthen or weaken the influence of organizational culture on organizational commitment. Even when it is analyzed by involving and not involving job satisfaction as the mediating variable of the influence of organizational culture on organizational commitment, volunteering tenure still does not strengthen or weaken the influence of organizational culture on organizational commitment. It is related to the psychological condition of the volunteers itself, whether they are new or old volunteers, everything starts from the individual call or will of the volunteers to help other people who need their help. They become volunteers in SSC organization because they want to be beneficial for other people

\section{Conclusions}

\subsection{Theoretical and Practical Implications}

This study provides significant theoretical and managerial implications through testing associations and attempting to deliver a framework for organizational commitment of volunteers in nonprofit organization and its theoretically related job satisfaction. In this regard, it presents empirical evidence that organizational culture have positive effect on job satisfaction, but not significantly related to commitment. However, organizational commitment is indirectly affected by organizational culture through job satisfaction. Furthermore, volunteering tenure is not a moderating variable on the relationships of organizational culture - commitment and job satisfaction - commitment. Results of this study are contradictory to McKinnon et al. (2003); Zain et al. (2009); Al-Amin and Noerjimati (2010) study on the relationship of culture and organizational commitment, therefore, 
further research could explore the effect of culture, along with job satisfaction as mediator on organizational commitment. The study is useful for understanding organizational culture, job satisfaction, and organizational commitment in non-profit organizations.

At a policy level, the results of the study indicate that organizational culture can benefit from instituting policies and practices aimed at fostering job satisfaction. For example, policies aimed at providing the effective communication through formal and non-formal meetings between members of the organization, provide a sense of equity and equality for all volunteers, enhance empathy, and encourage the use of technology. Organizational commitment can be enhanced through job satisfaction. For example, policies aimed at improving job satisfaction by ensuring that members of the organization have a strong motive to work as volunteers. In addition, members of the organization need to be appreciated through personal development and training policies.

\subsection{Limitation of the Study}

The questionnaire of this research has not added open question items. It is suggested for the further research to add open question items in order to gain more detail information related to the observed variable. It is better for the further research to broaden the research object on other non-profit organizations. It is also suggested that the next research adds other variables such as involvement and organizational citizenship behavior into research model.

\subsection{Conclusions}

Organizational culture does not have direct influence on volunteer's organizational commitment. A strong organizational culture has not yet been able to directly increase volunteer's commitment toward SSC organization Malang. Organizational culture influences the job satisfaction of volunteers, a strong organizational culture is able to increase the job satisfaction of the volunteers. Job satisfaction influences the organizational commitment of volunteers. Satisfied volunteers will be able to enhance their commitment toward organization. Job satisfaction fully mediates the influence of organizational culture on volunteer's organizational commitment. Organizational culture will be able to increase volunteer's commitment when it is able to enhance volunteer's job satisfaction. The volunteering tenure does not moderate or is not able to weaken or strengthen the influence of organizational culture toward the volunteer's organizational commitment.

\section{References}

Al-Amin, R. P., \& Noermijati. (2010). Kajian Tentang Nilai Nilai Inti Budaya Organisasi Dan Komitmen Anggota AIESEC Local Committee Universitas Brawijaya Malang. Jurnal Aplikasi Manajemen, 8(3), 607-616. Retrieved from http://www.jurnaljam.ub.ac.id/index.php/jam/article/download/201/231

Allen, N. J., \& Mayer, J. P. (1990). The Measurement and Antecedent of Affective, Continuance, and Normative Commitmen to Organization. Journal of Occupational Psychology, 63, 1-18. https://doi.org/10.1111/j.2044-8325.1990.tb00506.x

Bellou, V. (2010). Organizational culture as a predictor of job satisfaction: the role of gender and age. Career Development International, 15(1), 4-19. https://doi.org/10.1108/13620431011020862

Cartwright, J. (1999). Cultural Transformation: Nine Factors for Continuous Business Improvement. Financial Times/ Prentice Hall.

Dinar, W., \& Armanu, N. (2017). The Influence of Organization Culture and Motivation on the Voulenteer's Intention to Leave Mediated by the Work Satisfaction: A Study On Volunteers at Non Profit Organization Save Street Child in East Java Province. Russian Journal of Agricultural and Socio-Economic Sciences (ROJAS), 1(61), 137-147. https://doi.org/10.18551/rjoas.2017-01.14

Dirani, K. M. (2009). Measuring the Learning Organization Culture, organizational Commitment and Job Satisfaction in the Lebanese Banking Sector. Human Resource Development International, 12(2), 189-208. https://doi.org/10.1080/13678860902764118

English, B., Morrison, D., \& Chalon, C. (2010). Moderator effect of organizational tenure on the relationship between psychological climate and affective commitment. Journal of Management Development, 29(4), 394-408. https://doi.org/10.1108/02621711011039187

Hodgkinson, V. A. (2003). Volunteering in Global Perspective. In The Values of Volunteering, Springer: 35-53. Retrieved from Springer book series.

Jain, A. K. (2015). Volunteerism and organisational culture Relationship to organizational commitment and citizenship behaviors in India. Cross Cultural Management, 22(1), 116-144. 
https://doi.org/10.1108/CCM-11-2013-0167

Kotter, J. P, \& Heskett, S. L. (1997). Corporate Culture and Performance. translater Benyamin Molam. Jakarta: PT. Prenhallindo Simon \& Schruster (Asia) Pte Ltd.

Locke, E. A. (1970). Job Satisfaction and Job Performance: A Theoretical Analysis. Organizational Behavior and Human Performance, 5(5), 484-500. https://doi.org/10.1016/0030-5073(70)90036-X

Lund, D. B. (2003). Organizational culture and job satisfaction. Journal of Business \& Industrial Marketing, 18(3), 219-236. https://doi.org/10.1108/0885862031047313

Luthan, F. (2006). Perilaku Orgnisasi. Indonesian ed. Translater: Vivin Andika, dkk. Jogyakarta: Penerbit Andi.

MacIntosh, E. W., \& Alison, D. (2010). The Influence of Organizational Culture on Job Satisfaction and Intention to Leave. Sport Management Review, 13(2), 106-117. https://doi.org/10.1016/j.smr.2009.04.006

McKinnon, J. L., Harrison, G. L., Chow, C.W., \& Anne, W. (2003). Organizational Culture: Association With Commitment, Job Satisfaction, Propensity to Remain, and Information Sharing in Taiwan. International Journal Of Business Studies, 11(1), 25-44. Retrieved from http://www.researchgate.net

Meyer, J. P., \& Allen, N. J. (1991). A three-component conceptualization of organizational commitment. Human Resource Management Review, 1(1), 61-89. https://doi.org/10.1016/1053-4822(91)90011-Z

Noermijati. (2015). Peran kepemimpinan transforasional dan motivasi terhadap kinerja karyawan dengan moderasi masa kerja. Jurnal Keuangan dan Perbankan, 19(2), 326-335. Retrieved from http://jurnal.unmer.ac.id/index.php/jkdp/article/download/854/506

Prabowo, A., Alamsyah, A., \& Noermijati. (2016). Pengaruh kompensasi dan kepuasan kerja terhadap komitmen organisasional perawat dan bidan kontrak di RS Bhayangkara Hasta Brata Batu, Malang. Jurnal Aplikasi Manajemen, 14(1), 58-67. Retrieved from http://jurnaljam.ub.ac.id/index.php/jam/article/viewFile/848/778

Puspitawati, N. M. D. (2013). Kepuasan Kerja dan Komitmen Organisasional: Pengaruhnya Terhadap Kualitas Layanan Hotel Bali Hyatt Sanur. Thesis. Universitas Udayana, Denpasar. Retrieved from https://pps.unud.ac.id

Robbins, P., \& Judge, A. (2013). Organizational Behavior. NJ: Pearson Education, Inc.

Robbins, S. P. (2006). Perilaku Organisasi, translator Benyamin Molan, 10th ed. Indonesia: PT Mancanan Jaya

Yamsul, P. (2012). Pengaruh Motivasi dan Budaya Organisasi terhadap Kepuasan Kerja dan Komitmen Organisasional (Studi Pada Pengelola Program Nasional Pemberdayaan Masyarakat (PNPM) Di Provinsi Sulawesi Tenggara). Ph.D. Disertation, Universitas Brawijaya Malang, Indonesia.

Zain, Z. M., Razanita, I., \& Erlane, K. G. (2009). The Influence of Corporate Culture on Organisational Commitment: A Study on a Malaysian Listed Company. European Journal of Economics, Finance and Administrative Sciences, 17, 16-26. Retrieved from http://www.researchgate.net

Zeinabadi, H., \& Salehi, K. (2011). Role of procedural justice, trust, job satisfaction, and organizational commitment in Organizational Citizenship Behavior (OCB) of teachers: Proposing a modified social exchange model. Procedia-Social and Behavioral Sciences, 29, 1472-1481. https://doi.org/10.1016/j.sbspro.2011.11.387

\section{Copyrights}

Copyright for this article is retained by the author(s), with first publication rights granted to the journal.

This is an open-access article distributed under the terms and conditions of the Creative Commons Attribution license (http://creativecommons.org/licenses/by/4.0/). 